\title{
成長ひずみ法によるコンロッドの形状最適化の解析*
}

\author{
新井國夫 ${ }^{* 1}$, 水口義久 ${ }^{* 2}$, 鈴木徳仁 ${ }^{* 3}$

\section{Shape Optimization Analysis of Connecting Rod Using Growth-Strain Method} \\ Kunio ARAI ${ }^{* 1}$, Yoshihisa MINAKUCHI and Norihito SUZUKI \\ ${ }^{* 1}$ University of Yamanashi,Mechanical Systems Engineering, Department of \\ Education Interdisciplinary Graduate School of Medicine and Engineering \\ 4-3-11 Takeda, Kofu-shi, Yamanashi, 400-8511 Japan \\ Because of space restrictions and the necessity of minimum mass, the connecting rod is one of the more heavily \\ stressed parts of the car engine. The heaviest load occurs by gas pressure during firing at the top dead center position of the \\ piston. The second is tensile load which occurs by the inertia force of the piston assembly mass and around the small end of \\ the connecting rod mass. The third stress due to a lateral inertia, or "whip" of the connecting rod is usually negligibly small. \\ In this paper we investigated the optimization of the shape of the normal connecting rod for the car engine, applying the \\ growth-strain method. The analyses were done in case of compressive and tensile loads separately. The growth criterion \\ parameters of the principal stress on the connecting rod were determined from the fatigue strength of the original design data \\ and the actual safety factor. We thought that it is most compatible to use the fatigue strength which is the safety side, smallest \\ value of the material constants, because the connecting rod receives the reciprocating compressive and tensile hard loads. \\ After analysis, the optimized configurations of the connecting rod were compared with that of the original one. Then the \\ reduction rate of the volume of the optimized connecting rod was approximately $22.8 \%$.
}

Key Words : Optimum Design, Finite Element Method, Growth-Strain Method, Connecting Rod, Principal Stress

\section{1. 諸 言}

レシプロ式エンジンのコネクチングロッド（以下コンロッドと呼ぶ）は，実用的な内燃機関の発明が 19 世紀に 始まって以来，その形状は昔も今も基本的には変わりない．その機能としてはシリンダ一内で高温，高圧の蒸気 圧や石油系の燃料，又は可然性ガスなどの爆発圧力を受けるピストンの直線運動を，クランク軸の回転運動に結 びつけ，機械的エネルギーとして取り出すために必要な機能部品である.コンロッドには大型舶用ヂィーゼル機 関に見られるクロスヘッド型用の物と，それ以外のトランクピストン型用の物のタイプに分類出来る ${ }^{(1)}$. ここで は後者のタイプを研究対象としている.

近年時代の変遷につれて, 種々な用途に於いてエンジンに課せられる改善, 改良要求項目としては, (1) 重量当 たりの出力向上と 軽量化，(2) 燃料消費効率の向上，(3)製造コストの低減，(4)排出ガスのクリーン化などが挙 げられている，そこで重要なエンジン部品であるコンロッドについてのこれらに関連する改善研究例を観ると， Afzal, A. や山口等の研究 ${ }^{(2)(3)} に$ 見られる材料材質の開発では粉末鍛造材によるネットシェープや, 破断分離工法 に適した材料面による軽量化の改善研究がある. また Londhe, A. 等の研究(4)(5)(6)では，図 1 のように有限要素法 (FEM)を取り入れて, コンロッドに圧縮や引張の荷重を負荷して, 構造体の各部で疲労強度に対する応力が過大

\footnotetext{
*原稿受付 2011 年 4 月 26 日

${ }^{* 1}$ 学生員, 山梨大学大学院医学工学総合教育部（广400-8511 山梨県甲府市武田 4-3-11）

*2 正員, 山梨大学大学院医学工学総合研究部 (

*3 元山梨大学大学院医学工学総合教育部（广400-8511 山梨県甲府市武田 4-3-11）

E-mail: spxw6ye9@ray.ocn.ne.jp
} 
か，または過小かを解析したり，実物コンロッドにひずみゲージを各所に張り付けて，圧縮および引張の荷重を かけ，応力測定の結果とコンピュータ解析データを比較して，軽量化デザインの検討をした研究がある. しかし ながら, コンロッド形状の最適化設計法の研究に関しては, Shenoy 等の研究(7)で, 有限要素法と von Mises の応力 分布状況から，コンロッドのコラム部分の軽量化をした研究等が見られるが，コンロッド全体にわたる負荷応力 の均一化による軽量化の研究はまだ充分ではないと思われる.

そこで，本研究では上記の改善要求項目の解決策の一つとしてコンロッドの軽量化を目的に, 実際に小型自動 車用エンジンに使用されている図 2 に示すコンロッドを対象として三次元有限要素モデルを作成し，これに成長 ひずみ法を用いて形状創生解析をおこなった，本研究では，コンロッドに圧縮荷重と引張荷重が作用した場合に ついてそれぞれ成長解析し，応力の均一化を図りながら軽量化となる形状を目指した。 その際，成長則に入れる 基準忘力值は, 解析前における平均応力值でなく, 設計データの材料物性值中一番小さい疲労限強度を採用し, 実用の安全率で除した值とし，解析結果の安全性を見込んだ。また，コンロッド大端部の回転による慣性力から 発生するコラム部の曲げ応力については，後の 3.1 節で述べるように十分小さいのでここでは省略した.

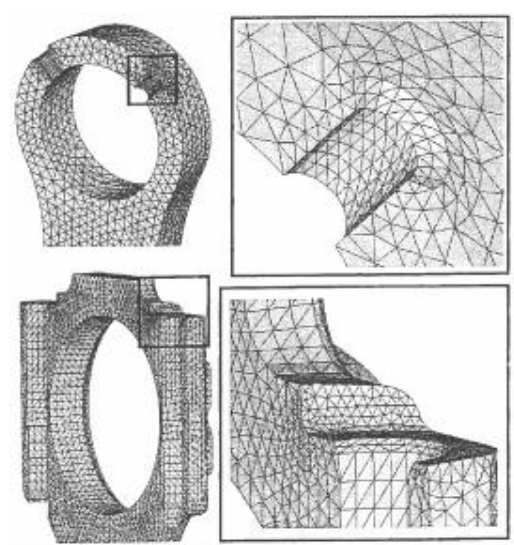

Fig.1 FEM analysis by Londhe et al..

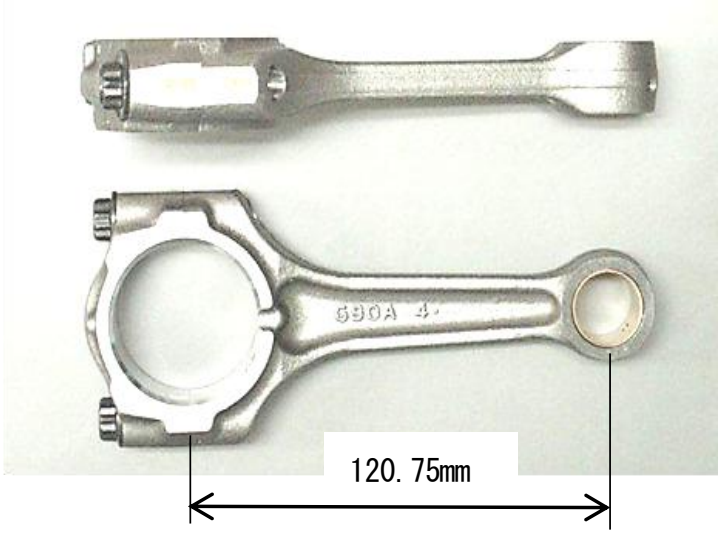

Fig.2 The shape of the connecting rod for analysis.

\section{2. 成長ひずみ法}

畔上氏らが提案された成長ひずみ法の原理(8) (9) を三次元に拡張した解析ソフトを用いた. 図 3 (a) は荷重 $P$ が物体に作用した時の成長ひずみ法の応力解析の概念図を示す，成長ひずみ法の原理は, 応力解析において

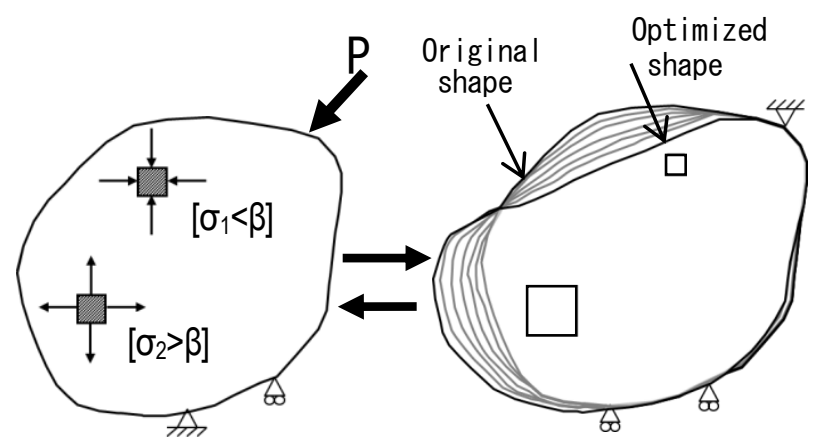

$\sigma_{1}$ and $\sigma_{2}$ :stress of elements

$\beta$ : Criterion parameter $P:$ Load

(a) Diagram in the case where stress analysis and growth analysis are performed repeatedly
Initial shape, Stress condition, Growth condition Shape (FEM)

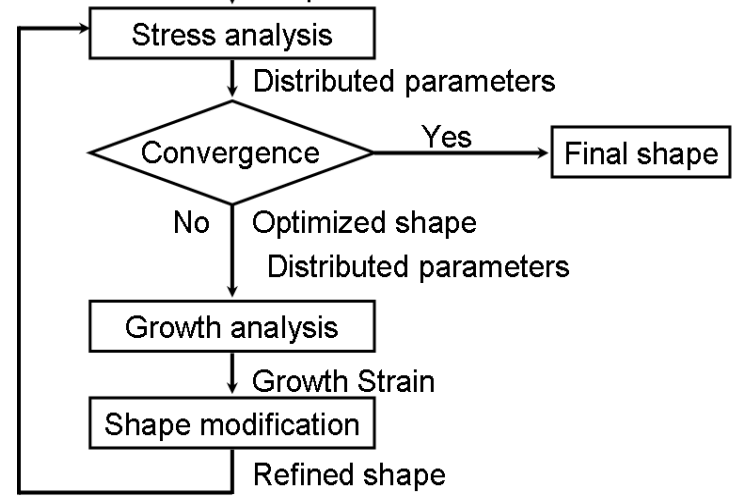

(b) Flow-chart of the growth-strain analysis

Fig.3 Principal of the growth-strain. 
物体中の各要素に生じる応力などの成長評価パラメータが 均一化するように, 体積ひずみを発生させて行くこと によって, 形状の最適化が行われる方法である. 図 3 (a) の物体中の各要素に生じる応力などの成長評価パラメ 一夕基準 $\sigma_{i}$ に対し, 目標とする基準值 $\beta$ を比較して有限要素法で解析する. 次に, 成長解析により $\sigma_{i}$ が $\beta$ の值 より小さければ，各要素の体積は収縮ひずみを発生させ，逆に $\beta$ の值より大きければ体積の膨張ひずみを，式 (1)の成長則に従って発生させる. そして物体内の各要素の評価パラメータが均一化され，体積変化率が $0 に$ に収 束し，形状変化が収まるまで計算を繰り返す．この規定回数解析を行った物体の形状を最適形状と見な寸手法で ある. 図 3(b) は成長ひずみ解析法のフローチャートを示す.

$$
\varepsilon^{G}=\frac{h}{\beta}\left(\max \left(\left|\sigma_{1}\right|,\left|\sigma_{2}\right|,\left|\sigma_{3}\right|\right)-\beta\right)
$$

ここで, $\varepsilon^{G}$ は成長ひずみテンソル， $\sigma_{1}, \sigma_{2}, \sigma_{3}$ は主応力, $h$ は一回の成長変形の大きさを表す成長係数を示す.

\section{3. 成長ひずみ法によるコンロッドの最適形状解析}

\section{$3 \cdot 1$ コンロッドの解析条件}

本解析では自動車用ガソリンエンジンに使用され，現在流動品のコンロッドを解析の対象にした．解析を行う 上で，コンロッドに与える負荷は，ピストンが上死点付近における最大爆発圧力の荷重と，排気工程上死点での ピストンアッセンブリおよび，コンロッド小端部付近の往復動成分などの質量から生じる慣性力による引張荷重 の二種類とし，それぞれで成長ひずみ法で解析した。 クランク軸の回転により発生するコンロッドのコラム部の 鞭打ち現象による曲げ荷重もあるが，この解析でモデルにしたコンロッドでは, 最高回転時 (6000r.p. m) での鞭打 ちによる最大モーメントは $12.4 \mathrm{~N} \cdot \mathrm{m}$ その時の曲げ応力は 19.3MPa であった. これは, コラム部にかかる圧縮応力 と,引張応力がそれぞれ $345 \mathrm{MPa}$ と 103MPaに比べ, 約 1/15〜1/5 となり,十分小さいと考えここでは省略した ${ }^{(1)}{ }^{(10)}$. 圧縮荷重と, 引張荷重を負荷した条件下での最適形状を創生することを目的に，ロッド部分とキャップ部分をボ ルトで組付けた状態で成長解析を行った．図 2 の写真に示した解析のモデルにしたコンロッドの材料の機械強度 物性值及び，寸法等の諸元を表 1 と図 4 に示寸. このエンジンのピストンの直径は $85 \mathrm{~mm}$ で, 疲労強度の $350 \mathrm{MPa}$ の值等は, 現行の設計データによるものである. なお, コンロッドの温度上昇は $200^{\circ} \mathrm{C}$ 程度なので材料強度は常 温での数值とした.

コンロッドの三次元有限要素モデルについての概要はメッシュサイズが $1.5 \mathrm{~mm}$, 節点数が 44925 個，要素 数が 222069 個で, 用いたコンロッドは材質が SCM435 の調質材で, 各種定数を表 2 と表 $3^{(11)(12)}$ に示した. 解析モデルは，汎用有限要素法プリポストプロセッサ FEMAP ver8.3 を使用して図 5 に示すように作成した.

Table 1 The details of the connecting rod and the engine capacity.

\begin{tabular}{|l|l|}
\hline Material & SCM435 \\
\hline Hardness & HRC22-31 \\
\hline Fatigue strength & $350 \mathrm{MPa}$ \\
\hline Compressive strength & $550 \mathrm{MPa}$ \\
\hline Max. pressure load & $40 \mathrm{kN}$ \\
\hline Max. tensile load & $12 \mathrm{kN}$ \\
\hline Bolt axial preload & $45 \mathrm{kN}$ (each) \\
\hline Piston diameter & $85 \mathrm{~mm}$ \\
\hline Max. engine rotation & 6000 r. p. m. \\
\hline
\end{tabular}

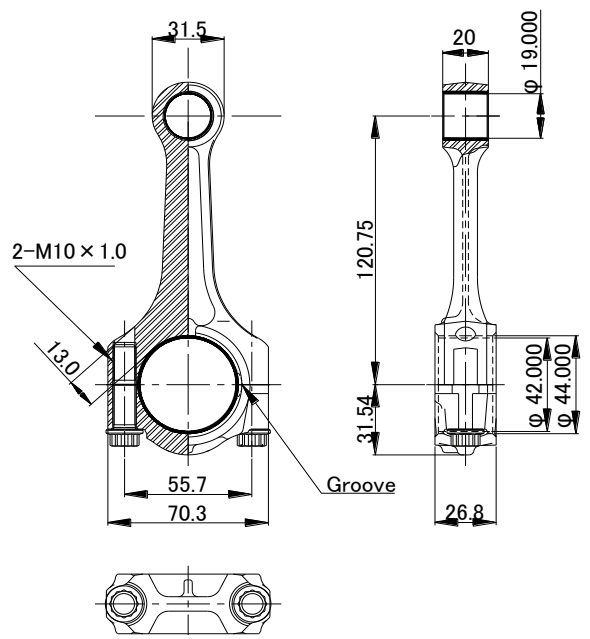

Fig.4 The shape \& dimension of the connecting rod for analysis. 
表 3 の基準值 $\beta$ の值は，通常では各構成部品に対して解析前の平均応力の值を用いるが，本解析ではコンロッ ドにかかる荷重が繰り返し荷重であることを考慮し，材料の強度物性值中，一番低い疲労強度を基に決め，解析 結果の安全性を見込んだ. それ故, 表 1 中の疲労強度の值を用い, 現在実用的な安全係数の 1.3 で除した值の 269 $\mathrm{MPa}$ とした. コンロッドにかかる荷重としては, 解析対象エンジンの諸元をもとに従来からある算出法(1) により， 燃焼最高爆発圧力による圧縮荷重 $40 \mathrm{kN}$ が小端部の内径下半分に等分布荷重でかかるとした．またピストンアッ センブリおよび，コンロッドの小端部付近の往復動成分の質量からなる, 慣性力による引張荷重 $12 \mathrm{kN}$ が小端部の 内径上半分に上向きに等分布荷重でかかる二種類とした。コンロッドボルトは，材質が SCM435 調質材で寸法は M10, ピッチ $1 \mathrm{~mm}$ で, 左右のボルトはそれぞれ 45kNでロッド大端部とキャップを締め付けた状態にある. 小端部内 径および，大端部内径にはベアリングが嵌っており，小端部の物はアルミ合金材料で，大端部の物は二重層から 成り，外側が SPCC 鋼材で，内側が銅合金材製である.ダミーはコンロッドのボルト穴が成長解析により内径側に 成長させないために, ボルトとの隙間に解析上設定した物で, 材質は SCM435 でコンロッドと同じ材料特性とした. ボルト，ベアリング類およびダミーについては，表 3 に示すようなヤング率 $E$ とポアソン比 $v$ であが，成長係 数 $h$ と基準值 $\beta$ は成長拘束し 0 とした．またコンロッドの大端部の内径面については，圧縮荷重時にはコラム側 を, 引張荷重時にはキャップ側半分を, 後述の図 7, 図 8 に示すようにY方向のみを単純拘束する条件とした.

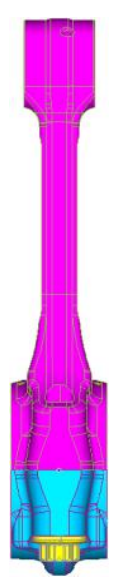

(a) Configuration of the modeled connecting rod for analysis

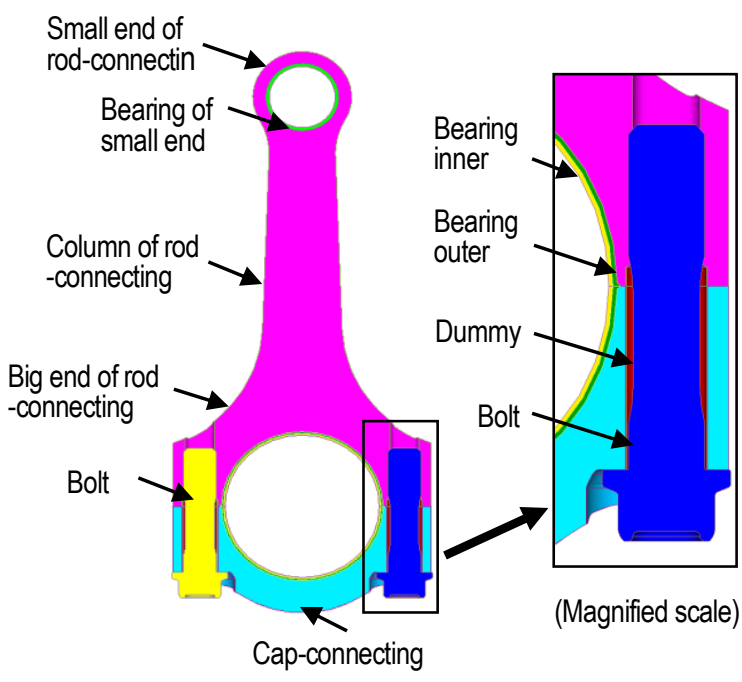

(b) Section divided by parts

Fig.5 The finite element model of the connecting rod for analysis.

Table 2 Datails of the elements.

\begin{tabular}{|l|c|}
\hline \multicolumn{1}{|c|}{ Item } & data \\
\hline Mesh size [mm] & 1.5 \\
\hline Number of nodes & 44925 \\
\hline Number of elements & 222069 \\
\hline
\end{tabular}

Table 3 Material properties of the connecting rod and those growth criterion parameters.

\begin{tabular}{|l|c|c|c|c|}
\hline \multicolumn{1}{|c|}{ Materials } & $\begin{array}{c}\text { Young's } \\
\text { modulus } \\
E[\mathrm{GPa}]\end{array}$ & $\begin{array}{c}\text { Poisson's } \\
\text { ratio } \\
v\end{array}$ & $\begin{array}{c}\text { Growth } \\
\text { ratio } \\
h\end{array}$ & $\begin{array}{c}\text { Criterion } \\
\text { parameter } \\
\beta[\mathrm{MPa}]\end{array}$ \\
\hline Rod:(SCM435) & 210.0 & 0.30 & 0.01 & 269 \\
\hline Cap:(SCM435) & 210.0 & 0.30 & 0.01 & 269 \\
\hline Bolt:(SCM435) & 210.0 & 0.30 & - & - \\
\hline Bearing of S/E: $(\mathrm{Al})$ & 70.3 & 0.34 & - & - \\
\hline Bearing of B/E inside: $(\mathrm{Cu})$ & 120.0 & 0.38 & - & - \\
\hline Bearing of B/E outside: $(\mathrm{spcc})$ & 205.0 & 0.30 & - & - \\
\hline Dummy:(SCM435) & 210.0 & 0.30 & - & - \\
\hline
\end{tabular}


さらに本解析で留意した条件として，この解析により大端部の形状変形が進んだ時，圧縮や引張による大端部 内径のクローズドイン現象により，クランクピンとの間で潤滑油膜が保てず，焼き付けを起こす原因になっては 解析結果が実用に適さない，そこで図 6 に示寸ようにコンロッド大端部で，ロッドとキャップの合せ面における 内径部側で，幅方向中心位置に基準ノードを左右（X 軸）それぞれに設定した，そしてその基準ノードの弾性変 形による移動量について，解析前の原形状での圧縮及び，引張時の初期弾性変形した位置を基準にし，そこから 設計者が想定する限度である, 左右ノードの変位がそれぞれ $0.005 \mathrm{~mm}$ まで内径側に移動する量を限度として解析 を行った．図 6 は解析初期の弾性変形がわかりやすいように変形量を 100 倍にして表してある.

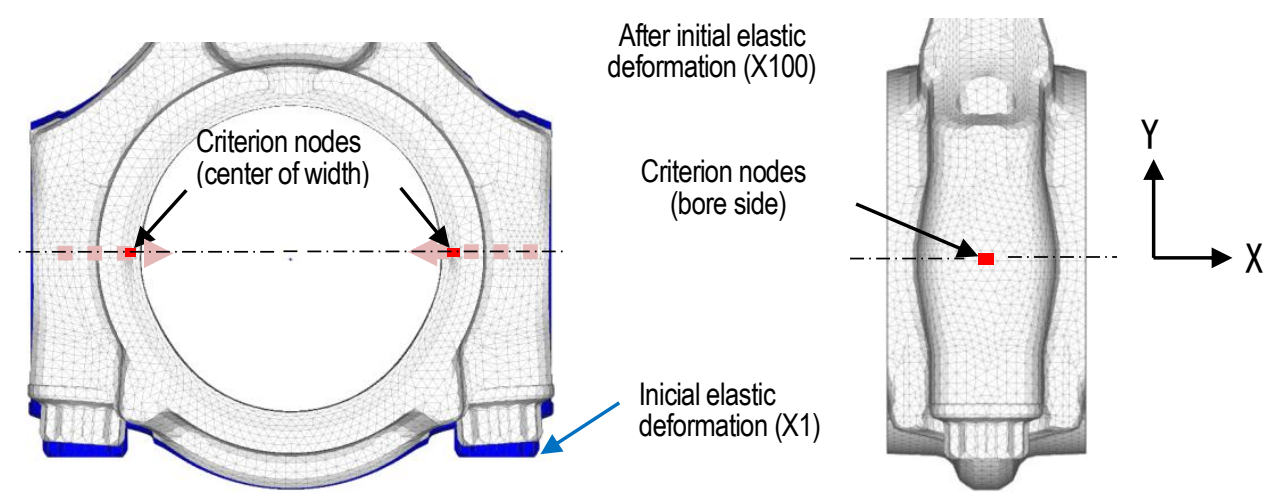

Fig.6 The criterion nodes were set on both side center of width of the bore.

\section{$3 \cdot 2$ 圧縮荷重に対するコンロッドの成長解析}

コンロッドにかかる圧縮荷重は，3.1 で述べたような力が働くものとし計算の結果 $40 \mathrm{kN}$ と設定した. その圧縮 荷重は図 7 に示すように小端部内径の下半分に下向きに等分布荷重とした. コンロッドボルトには $45 \mathrm{kN} の$ 締付力 が働いてロッド大端部と，キャップ部分を組み付けている．表 3 に示した $\beta$ 值は，3.1 節で述べたように $269 \mathrm{MPa}$ とし，成長係数 hは予備解析の結果 0.01 の值を用いて成長解析した. またロッド部分と，キャップ部分のタの 成長解析とするためボルト，ベアリング及びボルト穴のダミーの成長比率 $h$ は非成長すなわち 0 と設定し，大端 部内径の上半分について Y 方向を拘束した条件の下で，200 回繰り返し成長ひずみ解析を実施した後，形状を検 討した.

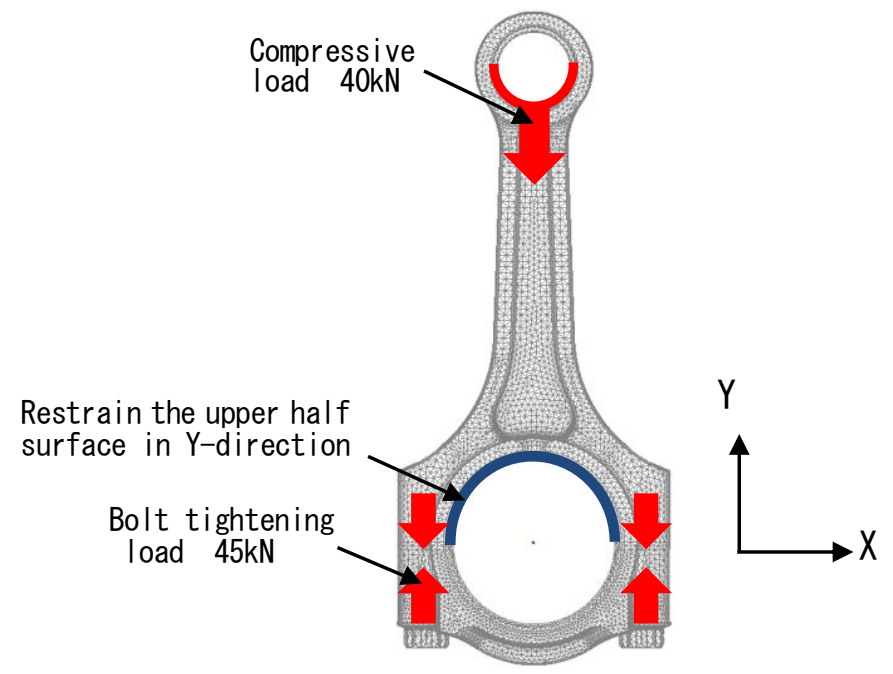

Fig.7 The compressive load condition on the connecting rod. 


\section{$3 \cdot 3$ 引張荷重に対するコンロッドの成長解析}

コンロッドにかかる引張荷重は，3.1 で述べたような力が働くものとし計算の結果 $12 \mathrm{kN}$ と設定した. その引張 荷重の条件を図 8 に示すように小端部上半分に上向きに等分布荷重とした. コンロッドボルトの締付力や，各部 分の基準值 $\beta$ と成長比率 $h$ の值及び，ボルトとベアリング及びボルト穴のダミーの成長比については 3.2 節と同 条件とし，また大端部内径部分の下半分についてY方向を拘束した条件で解析を行った. この条件の下で 200 回 の繰り返し成長ひずみ解析を実施した後，形状を検討した。

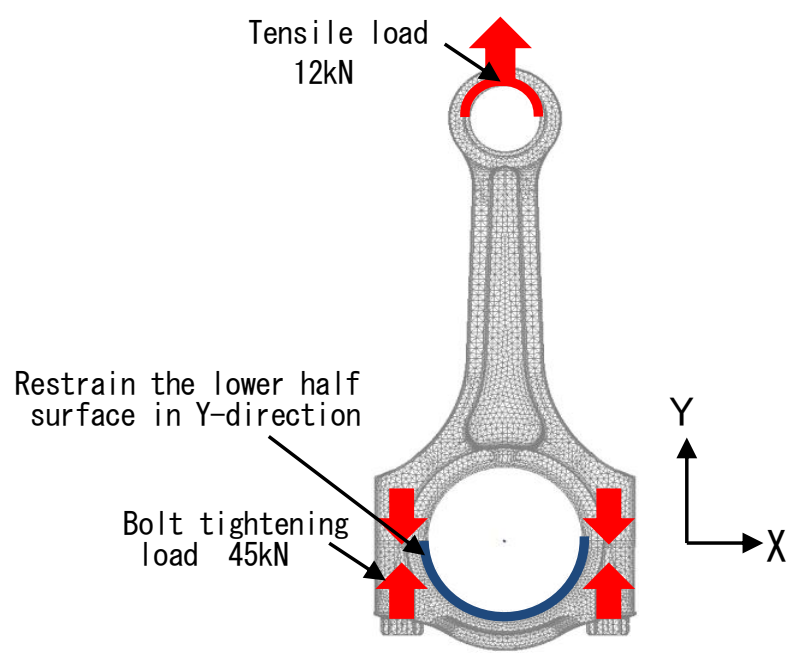

Fig.8 The tensile load condition on the connecting rod.

\section{4. 解析結果および考察}

\section{$4 \cdot 1$ 圧縮荷重条件での成長解析の回数と体積変化率および, 大端部基準ノードの変位量との関係}

3. 2 節で述べたコンロッドの圧縮荷重に対する成長解析の結果，得られた解析回数と体積変化率推移グラフを 図 9 に示す.これよりコンロッドのロッド部分とキャップ部分とも, 解析数の増加につれて体積変化率が 0 に収 束して行く傾向を示したので, 形状変化が収まって来たと判断出来る 200 回まで解析を実行した.

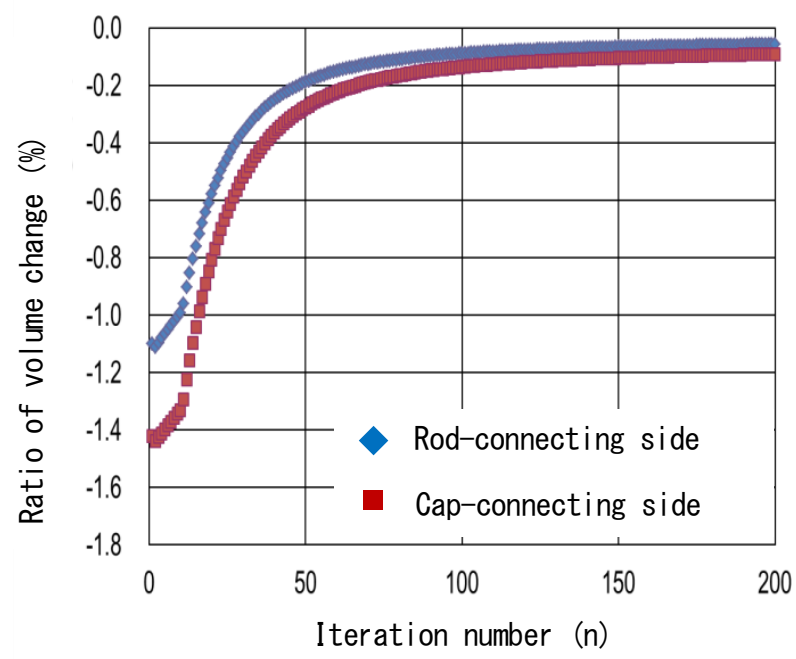

Ratio of volume change : $\left(V_{n}-V_{n}-1\right) / V n-1 \times 100(\%)$ $\mathrm{Vn}$ : The volume after analyzing $\mathrm{n}$ times

Fig.9 Relationships between ratio of volume change and iteration number.

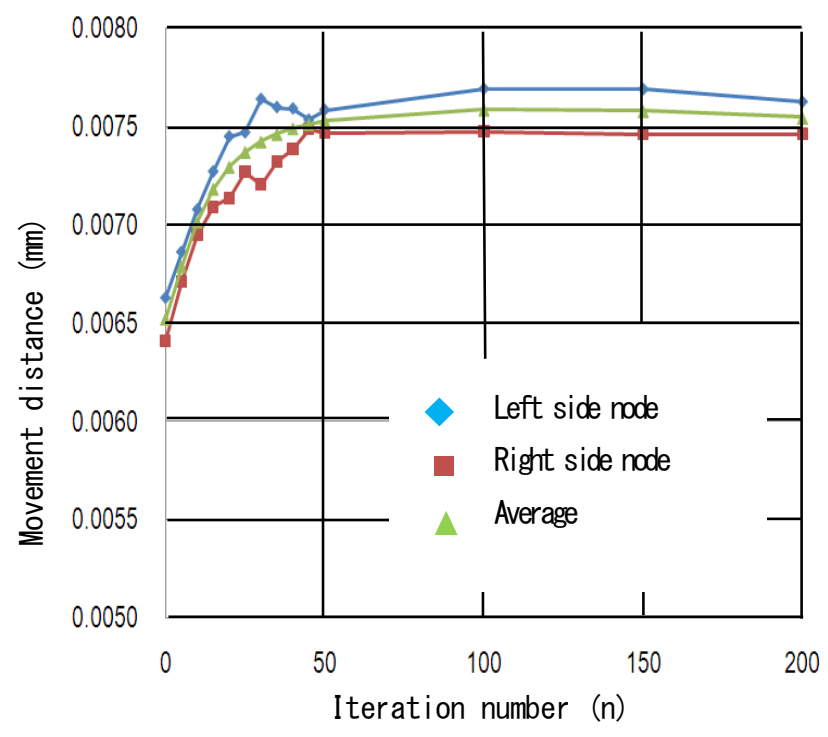

Fig.10 Relationships between movement distance of nodes and iteration number. 
更に図 6 で示したように，大端部内径面に設定した基準ノードの移動量を併せて計測し，解析回数と基準ノー ドの移動量の関係グラフを図 10 に示した. このグラフの横軸解析回数 0 での基準ノードの移動量は, オリジナル 形状で圧縮荷重 $40 \mathrm{kN}$ が掛かった時の弾性変位量を示している. その後荷重をそのままにして, 解析が進んで行っ た状況を表している．基準ノードの移動量は，左右ノードの変位量とその平均值の 3 種類を表している．この図 10 において左側ノード (Left side node) のカーブが僅かに右側ノード(Right side node)のカーブより変位量 が大きいのは，ロッドとキャップの合せ面位置にベアリングの回り止め溝が，図 5 (a)の平面図に於ける大端部の 左側のみロッドとキャップそれぞれに，幅 $3 \mathrm{~mm}$ ，深さ $1.5 \mathrm{~mm}$ ，切り上がり長さ $6.7 \mathrm{~mm}$ ，切削カッター半径 $10 \mathrm{~mm} の$ 半月状に切削加工されているためと考えられる. 解析回数と基準ノードの変位量は初期状態で左右とも $0.0065 \mathrm{~mm}$ 程度生じている. その後解析数 50 回過ぎまで連続的に変位量が増しているが, その後はほとんど変位がなく, 200 回まで解析を継続したが, 変位量の増加は約 $0.0012 \mathrm{~mm}$ で, 制限值の $0.005 \mathrm{~mm}$ 以内であったので, 成長解析回数 を200 回として体積変化と形状変化の結果を後節 4.4 で述べているように得た.

\section{$4 \cdot 2$ 引張荷重条件での成長解析の回数と体積変化率および, 大端部基準ノードの変位量との関係}

3. 3 節で述べたコンロッドの引張荷重に対する成長解析の結果, 得られた体積変化率推移グラフを図 11 に示す. このグラフより, コンロッドのロッド部分とキャップ部分とも, 解析数の増加につれて体積変化率が, 次第に小 さくなって行き, 150 から 200 回では変化率が小さく0に近い值なので, 圧縮時と同様に形状変化が収まってい ると判断した.

更に図 6 で示したように, 大端部内径面に設定した基準ノードの移動量を併せて計測し, 解析回数と基準ノー ドの移動量の関係グラフを図 12 に示した. このグラフの横軸の解析回数 0 での基準ノードの移動量は, オリジナ ル形状で引張荷重 $12 \mathrm{kN}$ が掛かった時の弾性変位量を示している. その後荷重をそのままにして, 解析が進んで行 った状況を表している．基準ノードの移動量は，左右ノードの変位量とその平均值の 3 種類を表している．引張 荷重においても左右ノードの変位量に僅かな差があるのは，4.1 節の圧縮の場合と同じ原因と考える. 基準ノー ドの変位量は, 初期状態で左右とも， $0.014 \mathrm{~mm}$ 程度生じている. 解析回数と基準ノードの変位量グラフでは, 解 析回数がおよそ 50 回までは比較的変位量が大きいが, それ以降は傾きは小さくなるが変位量増加が継続している 事を示している. 従って初期状態での変位量から成長解析による変位増分を，0.005mm までとする制限内での解 析回数は 52 回であった. 従って引張荷重に対しては解析回数を 52 回まで行った時の体積変化と形状変化の結果 を後節 4.4 で述べているように得た。

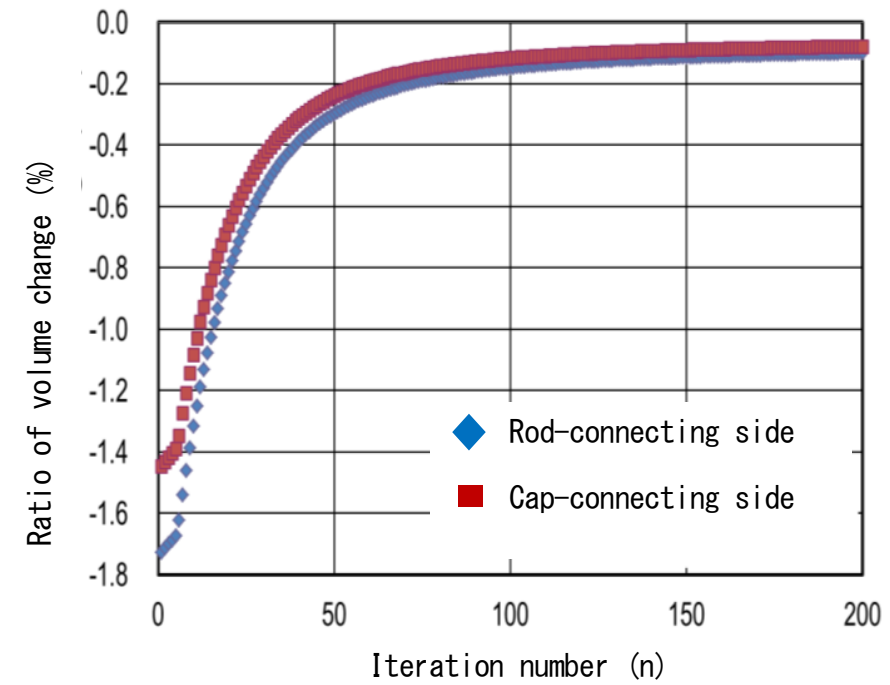

Ratio of volume change : $(V n-V n-1) / V n-1 \times 100(\%)$ $\mathrm{Vn}$ : The volume after analyzing $\mathrm{n}$ times

Fig.11 Relationships between the ratio of volume change and iteration number.

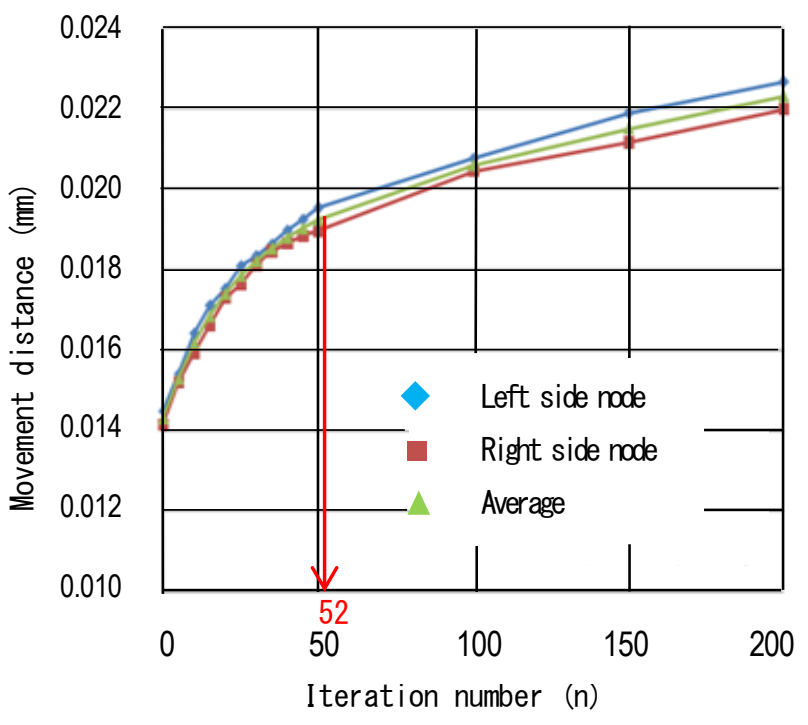

Fig.12 Relationships between Movement distance of the nodes and iteration number. 


\section{$4 \cdot 3$ 圧縮荷重及ひ，引張荷重に対する成長解析前後の von Mises 相当応力分布図と形状変化}

3.1 節の図 5 で示した解析用オリジナルコンロッドの 3D モデルを基に, 成長解析を行う前と後で, 得られた von Mises 相当応力分布図について, 圧縮荷重の場合を図 13 に, 引張荷重の場合を図 14 に示寸. 図 13 の圧縮荷 重の場合では，オリジナル形状でも小端部下からコラム部分にかけて，360-400 MPa 程度の応力があり，200 回解 析後にはコラム部分の中央部分や，小端部直下の体積膨張が見られる．またコラムを介して伝達される圧縮荷重 は大端部の上方では，コラムの幅よりあまり拡大されずに伝達されるように見える. 従って大端部外郭部と，コ ラムのつなぎ部分の体積减少が著しい. 大端部と小端部の圧縮荷重を受けない両先端部側も, 当然ながら体積減 少が大きい. 小端部直下でコラムとのつなぎ部分に応力值が 330-340MPa 程度の部分が残っているが, 解析回数を ふやせば基準值 $\beta$ 以下になるまで成長変形すると考えられる.

図 14 の引張荷重の場合では, オリジナル形状で最も高い応力值でも, 大端部のボルトによる締付荷重で $280 \mathrm{MPa}$ 程度である.コラム部分の応力值は 80-120MPa 程度なので, 52 回の解析数でも著しく体積の減少が見られた. 但 し，4. 2 節で述べたように，大端部内径に設定した，基準ノードの変位量の制限から，引張荷重に対しては大端 部の内側方向のクローズドインが大きく, コラムと大端部の外郭部とのつなぎ部分での体積減少は比較的少ない 結果となった. また $3 \mathrm{D}$ モデルでの形状変化を, 解析前の物と圧縮荷重解析の物および, 引張荷重解析の物とのそ れぞれの比較を図 15 に示寸.

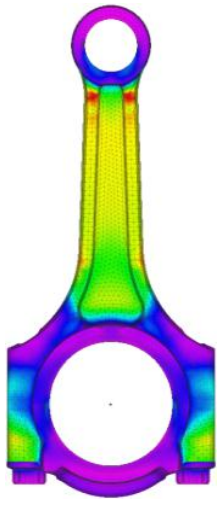

(a) Before analysis

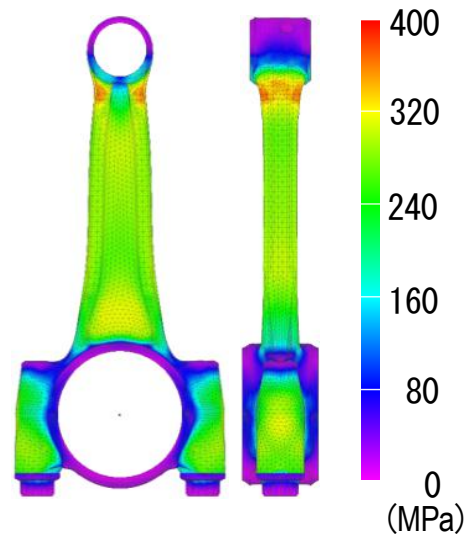

(b) After 200 times analysıs

Fig.13 Von Mises diagram on compressive. load.

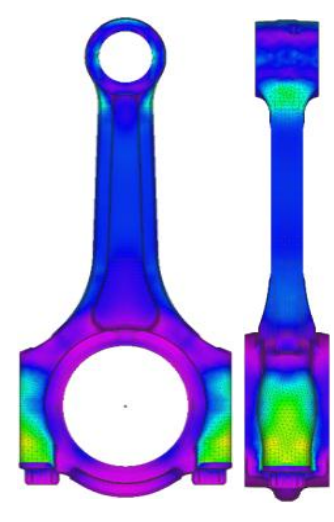

(a) Before analysis
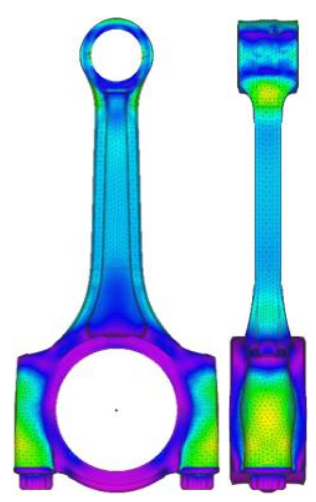

400

(b) After 52 times analysis

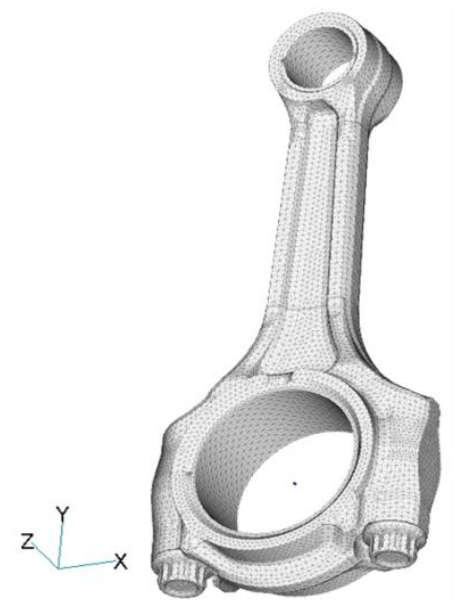

(a) Before analysis (Original shape)

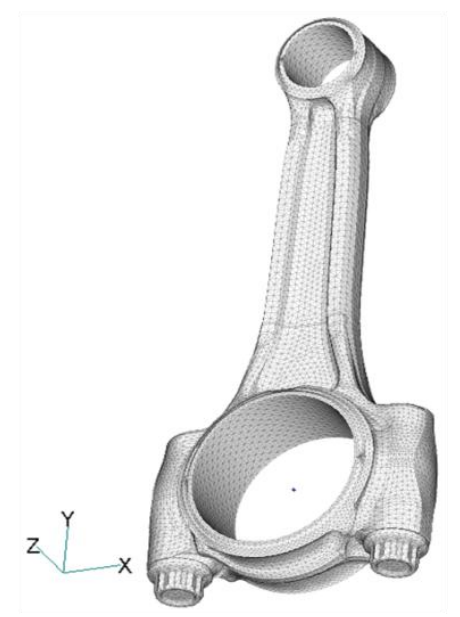

(b) After 200 times analysis (Under compressive load)

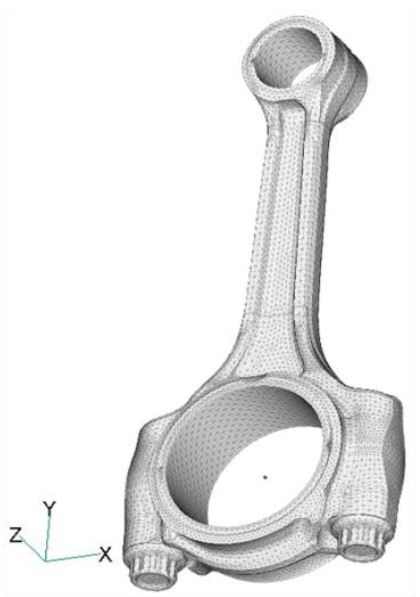

(c) After 52 times analysis (Under tensile load)

Fig.15 The comparison of the connecting rod-shapes which are before and after growth-strain analysis. 


\section{$4 \cdot 4$ 成長解析による形状変化に伴うコンロッド外郭形状と, 体積変化の結果}

以上の解析結果から, 圧縮荷重の解析回数は 200 回, 引張荷重の解析回数は 52 回まで実行した時, コンロッ ドの体積変化に伴う, 解析前の状態と圧縮荷重および, 引張荷重での解析後の各形状の違いを, 三種類に色分け して図 16 に示した. また圧縮荷重と引張荷重による成長解析後に得られた, コンロッドの各外郭線図の最も外側 （大きい方）の線を用いて得られた最外郭形状を，最適形状として図 17 に示した. この最適形状にすれば，従来 より軽量で強度的にも応力ばらつきの少ない安全なコンロッドを創生出来ると考えられる. 図 18 で示されたコン ロッドは従来の形状より，かなり余肉が除去されスリム化されている．しかし小端部からコラム部分の半分程の 長さでは，僅かに体積澎張が見られる．また小端部とコラムのつながり部分のくびれが少なくなり応力集中を緩 和する形状変化が見られる．コンロッドのコラム形状は，従来一般的に見られるような平面図における外形線が 直線的でなく, 図 17 に示すようなコラム形状の方がコンロッド全体として, 軽量化と座屈強度に優れていると考 えられる。

最適化形状としたコンロッドを, オリジナルのコンロッドと比較した時の, 体積の減少率の状況を, 図 18 に示 した.ここでは，コンロッドを大端部上半分から小端部に至るロッド側と，大端部下半分のキャップ側とに分け て，それぞれの体積減少率を表した。 その結果ロッド側では $20.3 \%$ ，キャップ側では $28 \%$ の減少となり，両方 の合計減少率は約 $22.8 \%$ という結果がえられた.

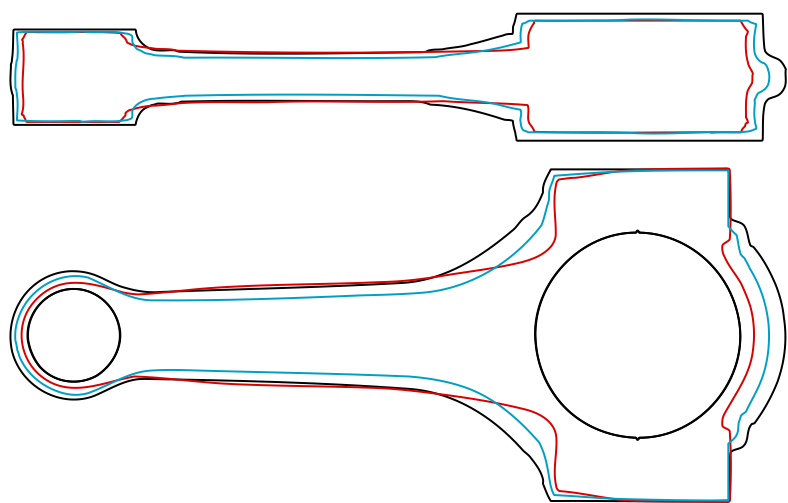

Original shape of connecting rod After compressive- load analysis After tensile- load analysis

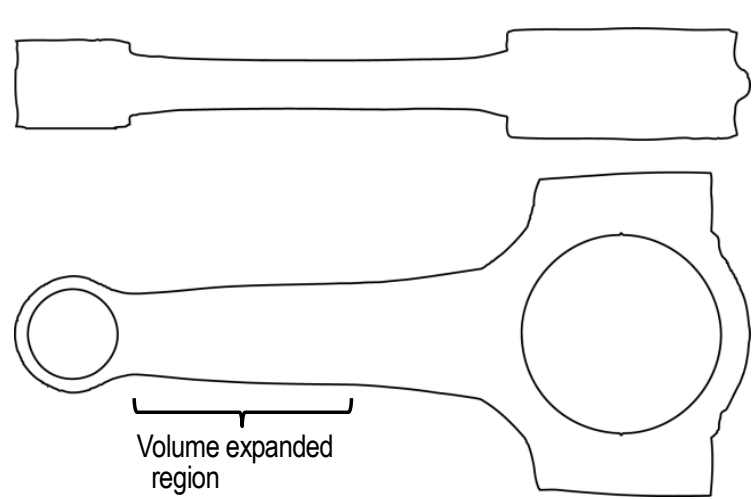

Fig.17 The shape of optimized connecting rod after growth-strain analysis.

Fig.16 The comparison of shapes of the original and the after growth-strain analysis.

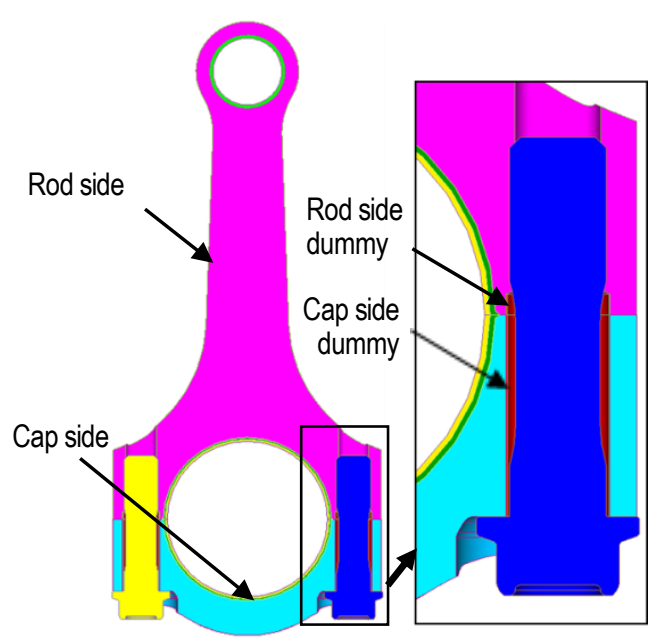

(a) Division of the connecting rod into the parts to calculate each volumes

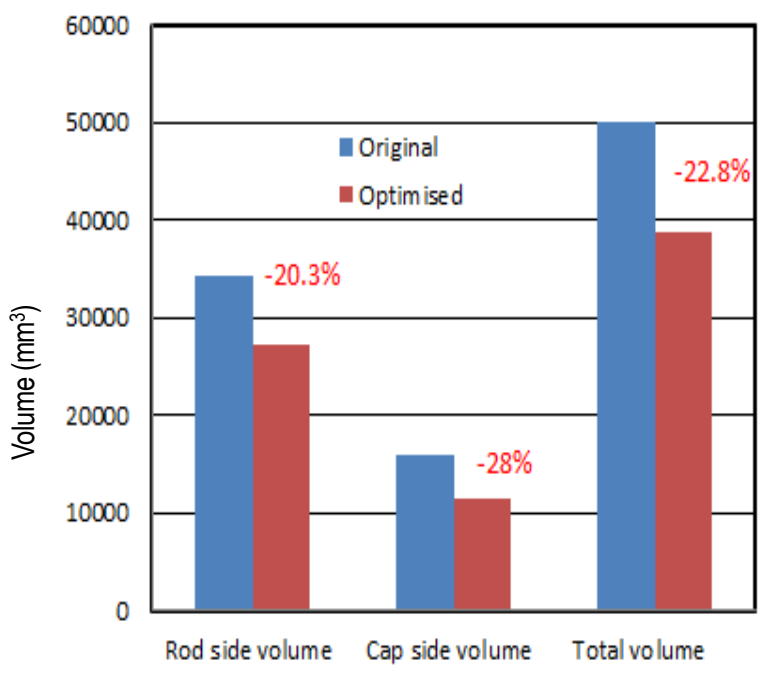

(b) The comparison of the volumes of the original connecting rod with the optimized shape one

Fig.18 The reduction in the volume of the optimized connecting rod. 


\section{5. 考 察}

本研究では，コンロッドに圧縮荷重と引張荷重が作用した場合について成長解析を行っており，いわゆ る部分両振れ応力の影響を考慮していないが，成長ひずみ解析に用いた基準応力值に材料の物性值中，疲 労限強度のデータを用いたことにより，解析結果の強度に安全性を見込んだ。更に，引張荷重の解析では 図 12 に示したように, 大端部内径のクローズドインの量で解析回数を制限しているという, 複雑な要素を ふくんでいる．しかしながら，コンロッドの疲労強度を確保して解析する考えからすれば，圧縮と引張の 繰り返し応力の最大応力振幅の值を，成長ひずみの評価基準値に用いる心゙きであったと考える．ここで改 めて本解析での現行品のコラム部にかかる最大圧縮応力と引張応力が，345MPa と $103 \mathrm{MPa}$ の值であること を用いて, 疲労強度の確認をする，最大応力振幅は $(345+103) \div 2=224 \mathrm{MPa}$ となり，また平均応力は (103-345) $\div 2=-121 \mathrm{MPa}$ となる. ここで疲労限度線図において用いる疲労限強度の值を表 1 の 350MPa の代 りに，今回の解析に用いた評価基準の $269 \mathrm{MPa}(=350 \div 1.3)$ を用いて，疲労強度を確認したところ，このコ ンロッドの最大応力振幅 $224 \mathrm{MPa}$ と，平均応力ー $121 \mathrm{MPa}$ で成す点が安全側にあることが確認できたので， 用いた評価基準の值が 269MPa でも，疲労強度を満たしていると考える.

さらに現行品コンロッドのコラム部の座屈強度を確認寸るには種々の計算式 ${ }^{(13)}$ ( (15) の Rankine の式 $(2)$ から座屈応力 $\sigma_{\mathrm{kf}}$ を計算する.ここで $\sigma_{\mathrm{D}}$ は材料の圧縮強度で, 表 1 のデータから $550 \mathrm{MPa}$, a は定数で $1 / 7500 ， \lambda$ は細長比でコンロッド長を断面二次半径で除した值で $47.1 ， \mathrm{c}$ は両端末の条件でこ こでは 4, としてこれらの数值を式(2)に代入すると, コラム断面の $\mathrm{X}, \mathrm{Y}$ 軸方向の内, 小さい方の座屈強度 として,

$$
\sigma_{\mathrm{kf}}=\sigma_{\mathrm{D}} /\left(1+\mathrm{a} \cdot \frac{\lambda^{2}}{\mathrm{c}}\right)=513 \mathrm{MPa}
$$

を得る.これをコラムにかかる最大爆発圧力からの圧縮応力 $\sigma_{\mathrm{c}}=345 \mathrm{MPa}$ と比較して安全率 $\mathrm{S}$ を求めると

$$
\mathrm{S}=\frac{\sigma_{\mathrm{kf}}}{\sigma_{\mathrm{C} 2}}=\frac{513}{345} \fallingdotseq 1.49
$$

となり，実用的安全率を満たしていると考える.

また，最適形状化後のコンロッドにおいて，回転による慣性力からの曲げ応力について考察すると，図 17 の最適形状は図 16 から解るように，コラム部の形状は解析前の形状より僅かに，体積の膨張が見られ る. 最大曲げモーメントは，小端部中心から大小端部中心間距離の約 $57 \%$ の位置にかかる(1)ので，最適形 状になった後でも，曲げ応力が解析前より大きくなる問題はないと考えられる.

さらに圧縮荷重の解析結果では, 図 16 と図 17 で示したように, 小端部からコラム部の半分程の長さで, 現行品より僅かに体積澎張となり意外性があった。このことは, 成長ひずみ法の特筆すべき結果で, 人間の 考えの及ばない一面と思われる. 今後は, 現行品と解析結果の最適形状としたもののエポキシ樹脂の試験片 を作成し, 圧縮と引張荷重での応力状態の改善度合いを光弾性理論応用の実験で, 比較検証してゆく予定で いる.

\section{6. 結}

小型自動車用エンジンコンロッドの大端部におけるロッドとキャップの合せ面近傍のクローズドインを片側 0.005mm (両側で $0.01 \mathrm{~mm}$ ) に制限した条件のもとで，圧縮荷重では 200 回，引張荷重では 52 回の成長ひずみ解 析を行った結果，以下の知見を得た.

1）大端部の内径クローズドインは, 圧縮荷重にくらべ引張荷重の影響が大きく, 最適化形状創生上では大端部 外郭からコラムにつながる部分は引張荷重の解析結果で外郭形状が決まった. 
2）圧縮荷重では小端部直下からコラムの中央部分にかけて，現行品よりも体積膨張が見られた．また 200 回の 成長解析後でも小端部からコラムの繫ぎ部分に von Mises 相当応力分布図では, 基準值より少し高い部分が 残るが，更に解析を継続すれば基準值以内に収まるまで形状変化が進むと考える.

3）圧縮と引張荷重による成長解析の結果得られた各外郭線の一番外側（大きい）の線を用いて創られる形状の コンロッドと，現在流動品のコンロッドの体積を比較すると，ロッド側の体積减少は 20.2\%，キャップ側は 28\%, トータルでは約 22. $8 \%$ の体積减少（軽量化）となり, 軽量かつ強度的に安全な最適形状のコンロッド の創生になったと考える.

\section{参考文献}

（1）長尾不二夫，内燃機関講義，上巻 (1965), pp .11-14, 302-304, 314-325, 養賢堂.

(2) Afzal, A., Fatemi, A., "A Comparative Study of Fatigue Behavior and Life Predictions of Forged Steel and PM Connecting Rods”, SAE Technical Paper Series, No. 2004-01-1529 (2004), pp. 1-12.

（3）山口雅史，大熊 悟，宮澤智則，山田雄一，”軽量一体鍛造分割型コンロッドの開発”, 日産技報, No.56 (2005), pp.21-24.

(4) Londhe, A., Yadav, V. and Sen, A., "Finite Element Analysis of Connecting Rod and Correlation with Test", SAE Technical Paper Series, No. 2009-01-0816, (2009) pp.1-11.

(5) Webster, W.D.Jr., Coffell, R. and Alfaro, D., "A Three Dimensional Finite Element Analysis of a High Speed Diesel Engine Connecting Rod”, SAE Technical Paper Series, No. 831322 (1983), pp. 83-96.

(6) Repgen, B., "Optimized Connecting Rods to Enable Higher Engine Performance and Cost Reduction", SAE Technical Paper Series, No. 980882 (1998), pp.1-5.

(7) Shenoy, P.S., Fatemi, A., "Connecting Rod Optimization for Weight and Cost Reduction", SAE Technical Paper Series, No.2005-01-0987 (2005), pp. 1-8.

（8）畔上秀幸, “成長の構成則を用いた形状最適化手法の提案”, 日本機械学会論文集 A 編, Vol. 54, No.508 (1988), pp. 2167-2175.

（9）下田昌利，畔上秀幸，桜井俊明，“成長ひずみ法によるソリッド体の形状最適化”，日本機械学会論文集 A 編, Vol.60 No.571(1994), pp.173-179.

(10) Taylor, C. F., The Internal - Combustion Engine in Theory and Practice Vol.2 (1968), pp.487-489, THE M.I.T. PRESS.

(11) 国立天文台編, 理科年表, Vol.67 (1994), p.444, 丸善.

(12）阿部孝行, 金澤健二, 西島 敏, “化学成分と熱処理による機械構造用鋼の弾性係数の変化”, 日本機械学会論文 A 編, Vol.62, No.602 (1996), pp.104-110.

(13) 衛藤洋仁, 松井勝幸, 福田晋作, 安藤柱, “ディーゼルエンジン用コネクティングロッドの高強度軽量化手法”, 圧 力技術, Vol.41, No.5, (2003), pp.224-232.

(14) 小熊正，機械設計演習エンジン編，(1965), pp.44-49, パワー社.

(15) JSMEテキストシリーズ, 材料力学, (2007), pp.119-130, 日本機械学会. 